\title{
Implementasi Logika Fuzzy Mamdani untuk Mendeteksi Kerentanan Daerah Banjir di Semarang Utara
}

\author{
Saiful Arifin ${ }^{1}$, Much Aziz Muslim², Sugiman ${ }^{3}$ \\ ${ }^{1,3}$ Jurusan Matematika, FMIPA, Universitas Negeri Semarang \\ ${ }^{2}$ Jurusan Ilmu Komputer, FMIPA, Universitas Negeri Semarang \\ Email: ${ }^{1}$ saifularifin_4111411017@yahoo.com, ${ }^{2}$ a212muslim@yahoo.com, ${ }^{3}$ sgmwp@yahoo.com
}

\begin{abstract}
Abstrak
Kerentanan (Vuinerability) adalah keadaan atau kondisi yang dapat mengurangi kemampuan masyarakat untuk mempersiapkan diri menghadapi bahaya atau ancaman bencana. Logika Fuzzy adalah cara untuk memetakan suatu ke dalam suatu ruang output. Salah satu aplikasi logika Fuzzy adalah untuk menentukan kerentanan daerah banjir di Semarang Utara. Pengujian dilakukan dengan metode Mamdani Fuzzy Inference System. secara manual dan program menggunakan 5 defuzifikasi, yaitu Centroid, SOM (Smallest Of Maximum), LOM (Large Of Maximum), MOM (Mean Of Maximum), Bisector. Dari 2 contoh kasus diperoleh hasil pengujian dengan kesimpulan yang sama.
\end{abstract}

Kata Kunci: Kerentaan, Fuzzy, Mamdani, Banjir, Matlab.

\section{PENDAHULUAN}

Semarang sebagai ibu kota Jawa Tengah mengalami banyak perkembagan dan pembangunan setiap tahunya. Lengkapnya infrastruktur dan fasilitas didukung akses yang mudah untuk menuju Ibu Kota Jawa Tengah ini menjadikan Kota Semarang salah satu kota untuk mengadu nasib. Akibat banyaknya pendatang ditambah penduduk pribumi Semarang termasuk kota dengan kepadatan penduduk yang tinggi. Akibatnya muncul beragam masalah salah satunya masalah lingkungan.

Salah satu masalah lingkungan adalah banjir. Banjir menjadi bencana tahunan yang sampai sekarang masih menjadi tugas pemerintah Kota Semarang dalam penanggulanganya. Banyak faktor yang menjadi penyebab banjir baik alam maupun manusia [1]. Banjir yang disebabkan alam seperti curah hujan, pengaruh fisiologi sungai, erosi dan sedimentasi, kapasitas sungai, kapasitas draenase, pengaruh air pasang. Sementara banjir disebabkan oleh faktor manusia antara lain perubahan kondisi das, wilayah kumuh, sampah, kerusakan bangunan pengendali banjir, dll.

Pada musim penghujan, banjir lebih disebabkan oleh kiriman yang terjadi karena lahan hulunya menerima hujan besar yang mengalir kedaerah hilirnya. Sedangkan pada musim kemarau, banjir disebabkan oleh adanya air laut sama dengan atau bahkan melebihi tinggi elevasinya terhadap suatu daerah, sehingga saat pasang air laut pasang terjadi genangan dialiran sungai maupun pada daerah rendah atau sering dikenal banjir rob.

Kondisi topografi yang datar dan rendah di wilayah utara dan berupa pegunungan diwilayah selatan menjadi salah satu penyebab banjir di Semarang. Wilayah Semarang Utara merupakan daerah rawan terhadap banjir dan rob. Terletak di pantai Semarang secara langsung berbatasan dengan Laut Jawa. Rata-rata ketinggian air tanah tidak jauh dari permukaaan air laut membuat banjir sering terjadi di daerah ini. 
Selain saat musim hujan di Semarang Utara, saat musim kemarau juga terjadi banjir rob, hal itu disebabkan karena dimensi saluran yang tidak memadai untuk menampung debit air pasang yang masuk ke sungai menyebabkan air melimpah ke daratan.

Logika Fuzzy pertama kali diperkenalkan oleh Prof. Lotfi A. Zadeh pada tahun 1965 [2]. Dasar logika Fuzzy adalah teori himpunan Fuzzy. Dalam logika Fuzzy terdapat fungsi keanggotan. Menurut Kusumadewi [3], fungsi keanggotaan adalah suatu kurva yang menunjukkan pemetaan titik-titik input data ke dalam nilai keanggotaanya yang memiliki interval antara 0 sampai 1 . Salah satu aplikasi logika Fuzzy yang telah berkembang amat luas dewasa ini adalah sistem inferensi Fuzzy (Fuzzy Inference System/FIS), yaitu kerangka komputasi yang didasarkan pada teori himpunan Fuzzy, aturan Fuzzy berbentuk IF THEN, dan penalaran Fuzzy. Ada tiga metode dalam sistem inference Fuzzy yang sering digunakan, yaitu Tsukamoto, Mamdani,dan Takagi Sugeno.

Sebagai salah satu metode dalam Fuzzy, Mamdani banyak diaplikasikan dalam kehidupan, salah satunya adalah implementasi logika Fuzzy Mamdani untuk mendeteksi kerentanan daerah banjir di Semarang Utara. Adapun untuk faktor-faktor yang mempengaruhi banjir di Semarang Utara disampaikan penulis adalah curah hujan, draenase, ketinggian wilayah, dan kepadatan penduduk. Untuk mendapatkan output kerentanan berupa aman, rawan, dan banjir, diperlukan 4 tahapan yaitu pembentukan himpunan Fuzzy, aplikasi fungsi implikasi, komposisi aturan, dan penegasan.

\section{METODE}

Permasalahan yang diangkat adalah bagaimana mengimplementasikan logika Fuzzy Mamdani untuk mendeteksi kerentanan daerah banjir di Semarang Utara dan membangun program deteksi kerentanan daerah banjir di Semarang Utara dengan bantuan software Matlab R2013a berbasis Mamdani Fuzzy Inference System. Pemecahan masalah dimulai dengan mengumpulkan data faktor penyebab banjir dari dinas atau instansi terkait. Setelah data diperoleh kemudian kemudian dihitung menggunakan metode Mamdani Fuzzy Inference System, kemudian membangun program kerentanan banjir di Semarang Utara menggunakan GUI Matlab R2013a.

\subsection{Pembangunan Aplikasi Program Deteksi Kerentanan Bajir}

Untuk melakukan proses deteksi kerentanan banjir di Semarang Utara dibuat aplikasi deteksi kerentanan menggunakan metode Fuzzy Inference System dengan software Matlab R2013a. Proses pembuatan perangkat lunak aplikasi kerentanan menggunakan model sekuensial linear (waterfall), model waterfall terlihat pada Gambar 1.

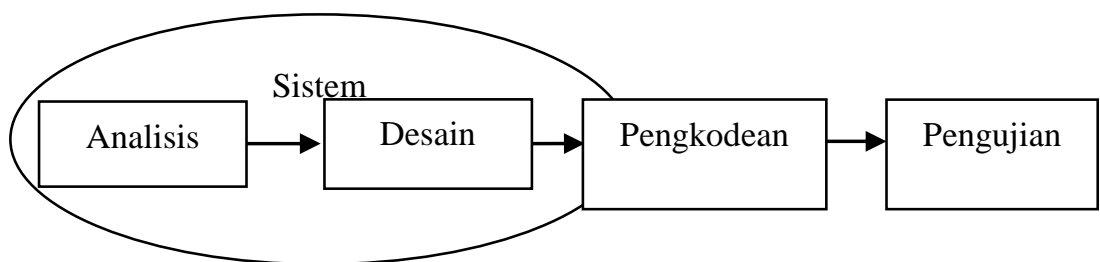

Gambar 1. Model Waterfall 
Model Waterfall digunakan untuk pengembangan perangkap lunak secara sistematik dan sekuensial yang dimulai pada tingkat dan kemajuan sistem melalui analisis, desain, kode, dan pengujian. Tahap analisis merupakan tahap menganalisis hal-hal yag diperlukan dalam pelaksanaan pembuatan perangkat lunak. Tahap desain merupakan tahap penerjemahan dari data yang dianalisis kedalam bentuk yang mudah dimengerti oleh user. Pada tahap ini dilakukan proses desain aplikasi kerentanan banjir menggunakan metode Mamdani Fuzzy Inference System. tahap pengkodean merupakan tahap penerjemahan data atau pemecahan masalah yang telah dirancang kedalam bahasa pemrograman. Pada tahap ini dilakukan pengkodean terhadap desain aplikasi kerentanan banjir di Semarang Utara yang telah dibuat kedalam bahasa pemrograman dari software Matlab R2013a. Selanjutnya adalah tahap pengujian terhadap perangkat lunak aplikasi kerentanan banjir. Pada tahap ini bertujuan untuk mencocokan nilai kesimpulan dari perhitungan manual dengan kesimpulan dan nilai pada program.

Beberapa proses yang harus dilakukan disajikan dalam diagram alir aplikasi kerentanan banjir yang disajikan pada Gambar 2.

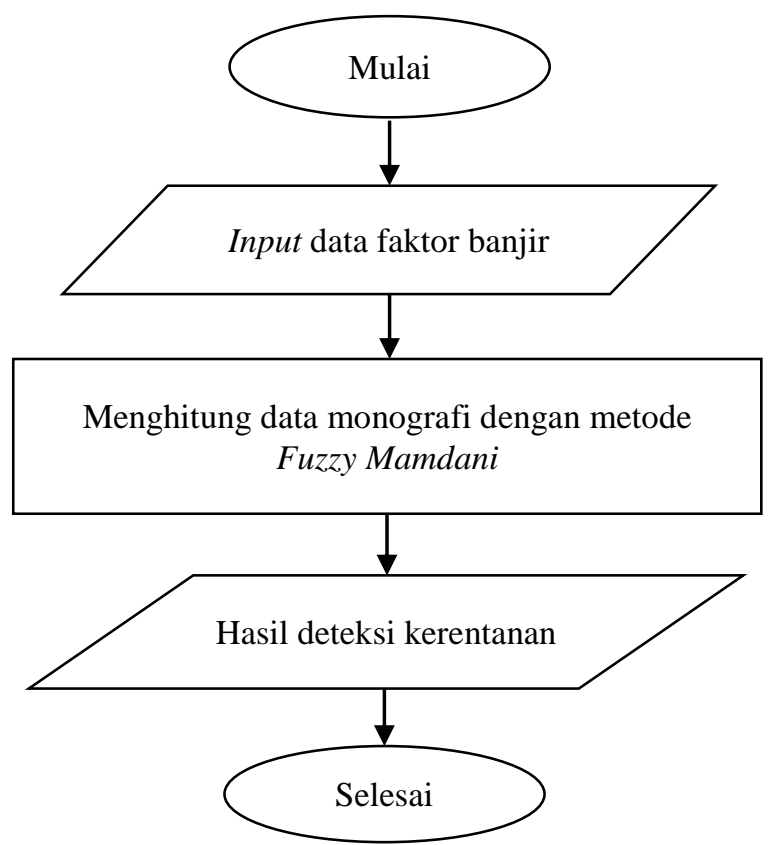

Gambar 2. Diagram alir kerentanan banjir

\section{HASIL DAN PEMBAHASAN}

\subsection{Tahap Pegumpulan dan Pengolahan Data}

Data yang digunakan adalah data faktor penyebab terjadinya banjir meliputi kepadatan penduduk perkelurahan tahun 2014, luas das dan kemiringan lahan dari masterplan drainase Kota Semarang Dinas Pengelola dan Sumber daya Air (PSDA), 
ketinggian wilayah Semarang Utara perkelurahan tahun 2014 dari BPS Kota Semarang, dan curah hujan.

Dari 5 variabel tersebut ditransformasikan dalam bentuk Fuzzy sebagai berikut.

1) Variabel Kepadatan Penduduk

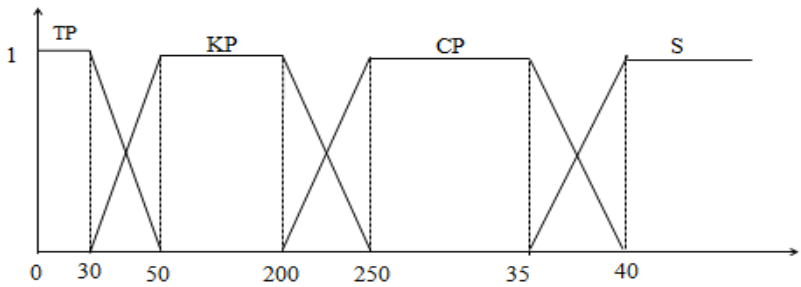

Gambar 3. Variabel kepadatan penduduk

Persamaan fungsi keanggotaan untuk variabel kepadatan penduduk dinyatakan menggunakan persamaan (1), persamaan (2), persamaan (3), dan persamaan (4).

$$
\begin{aligned}
& \mu_{P T P}[x]=\left\{\begin{array}{c}
1, x \leq 30 \\
\frac{50-x}{20}, 30 \leq x \leq 50 \\
0, x \geq 50
\end{array}\right. \\
& \mu_{P K P}[x]=\left\{\begin{array}{c}
0, x \leq 30 \text { atau } x \geq 250 \\
\frac{x-30}{20}, 30 \leq x \leq 50 \\
\frac{250-x}{50}, 200 \leq x \leq 250 \\
1,50 \leq x \leq 200
\end{array}\right. \\
& \mu_{P C P}[x]=\left\{\begin{array}{c}
\frac{x-200}{50}, 200 \leq x \leq 250 \\
\frac{400-x}{50}, 350 \leq x \leq 400
\end{array}\right. \\
& \mu_{P S P}[x]=\left\{\begin{array}{c}
1,250 \leq x \leq 350 \\
0, x \leq 350
\end{array}\right.
\end{aligned}
$$

2) Variabel Drainase

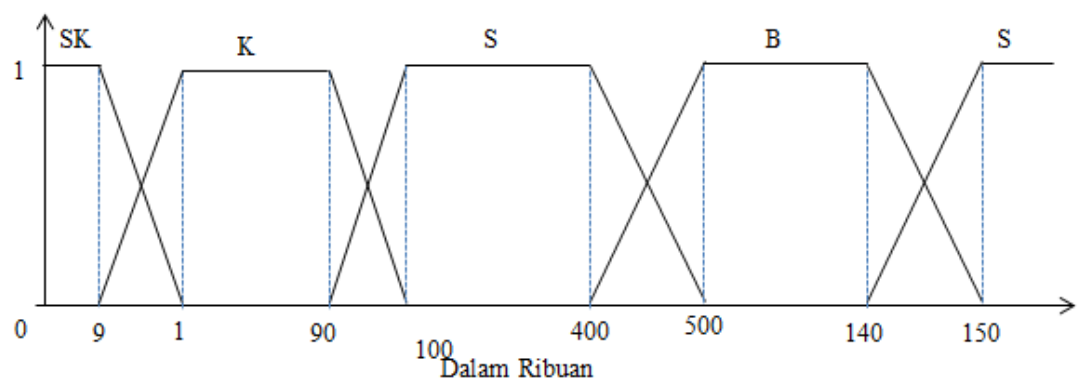

Gambar 4. Kurva himpunan Fuzzy pada variabel drainase 
Persamaan fungsi keanggotaan untuk variabel drainase dinyatakan menggunakan persamaan (5), persamaan (6), persamaan (8), persamaan (9), dan persamaan (10).

$$
\begin{aligned}
& \mu_{D S K}[x]=\left\{\begin{array}{c}
1, x \leq 9000 \\
\frac{10.000-x}{1000}, 9000 \leq x \leq 10.000 \\
0, x \geq 10.000
\end{array}\right. \\
& \mu_{D K}[x]=\left\{\begin{array}{c}
0, x \leq 9.000 \text { atau } x \geq 100.000 \\
\frac{x-9.000}{1000}, 9.000 \leq x \leq 10.000 \\
\frac{100.000-x}{10.000}, 90.000 \leq x \leq 100.000 \\
1,10.000 \leq x \leq 90.000
\end{array}\right. \\
& \mu_{D S}[x]=\left\{\begin{array}{c}
0, x \leq 90.000 \text { atau } x \geq 500.000 \\
\frac{x-90.000}{10.000}, 90.000 \leq x \leq 100.000 \\
\frac{500.000-x}{50.000}, 450.000 \leq x \leq 500.000 \\
1,100.000 \leq x \leq 450.000
\end{array}\right. \\
& \mu_{D B}[x]=\left\{\begin{array}{c}
0, x \leq 450.000 \text { atau } x \geq 1.500 .000 \\
\frac{x-450.000}{50.000}, 450.000 \leq x \leq 500.000 \\
\frac{1.500 .000-x}{100.000}, 1.400 .000 \leq x \leq 1.500 .000 \\
1,500.000 \leq x \leq 1.400 .000
\end{array}\right. \\
& \mu_{D S K}[x]=\left\{\begin{array}{c}
0, x \leq 1.450 .000 \\
\frac{x-1.400 .000}{100.000}, 1.400 .000 \leq x \leq 1.500 .000 \\
1, x \geq 1.500 .000
\end{array}\right.
\end{aligned}
$$

3) Variabel Kelerengan

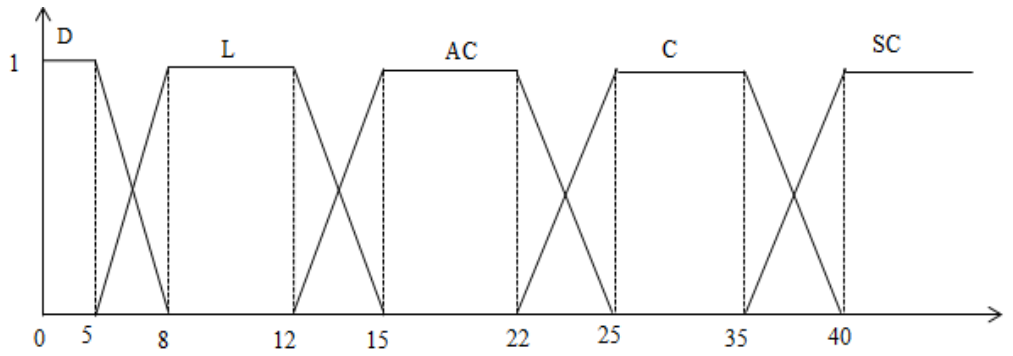

Gambar 5. Kurva himpunan Fuzzy pada kelerengan

Persamaan fungsi keanggotaan untuk variabel lereng atau kemiringan lahan dinyatakan menggunakan persamaan (10), persamaan (11), persamaan (12), persamaan (13), dan persamaan (14). 


$$
\begin{aligned}
& \mu_{L D}[x]=\left\{\begin{array}{c}
1, x \leq 5 \\
\frac{8-x}{3}, 5 \leq x \leq 8 \\
0, x \geq 8
\end{array}\right. \\
& \mu_{L L}[x]=\left\{\begin{array}{c}
0, x \leq 5 \text { atau } x \geq 15 \\
\frac{x-5}{3}, 5 \leq x \leq 8 \\
\frac{15-x}{3}, 12 \leq x \leq 15 \\
1,8 \leq x \leq 12
\end{array}\right. \\
& \mu_{L A C}[x]=\left\{\begin{array}{c}
\frac{x-12}{3}, 12 \leq x \leq 15 \\
\frac{25-x}{3}, 22 \leq x \leq 25 \\
1,15 \leq x \leq 22
\end{array}\right. \\
& \mu_{L C}[x]=\left\{\begin{array}{c}
0, x \leq 22 \text { atau } x \geq 40 \\
\frac{x-22}{3}, 22 \leq x \leq 25 \\
\frac{40-x}{5}, 35 \leq x \leq 40 \\
1,25 \leq x \leq 35
\end{array}\right. \\
& \mu_{L S C}[x]=\left\{\begin{array}{c}
\frac{40-x}{5}, 35 \leq x \leq 40 \\
1, x \geq 40
\end{array}\right.
\end{aligned}
$$

4) Variabel Ketinggian Wilayah

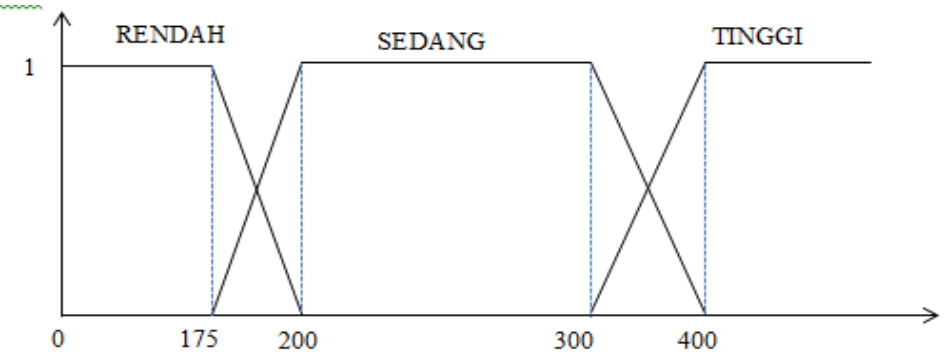

Gambar 6. Kurva himpunan Fuzzy pada variabel ketinggian

Persamaan fungsi keanggotaan untuk variabel ketinggian lahan dinyatakan menggunakan persamaan (15), persamaan (16), dan persamaan (17).

$\mu_{\text {KTRendah }}[x]=\left\{\begin{array}{c}1, x \leq 175 \\ \frac{200-x}{25}, 175 \leq x \leq 200 \\ 0, x \geq 200\end{array}\right.$ 


$$
\begin{aligned}
& \mu_{\text {KTSedang }}[x]=\left\{\begin{array}{c}
0, x \leq 175 \text { atau } x \geq 400 \\
\frac{x-175}{25}, 175 \leq x \leq 200 \\
\frac{400-x}{50}, 350 \leq x \leq 400 \\
1,200 \leq x \leq 300 \\
0, x \leq 300
\end{array}\right. \\
& \mu_{\text {KTTinggi }}[x]=\left\{\begin{array}{c}
\frac{x-300}{100}, 300 \leq x \leq 400 \\
1, x \geq 400
\end{array}\right.
\end{aligned}
$$

5) Variabel Curah Hujan

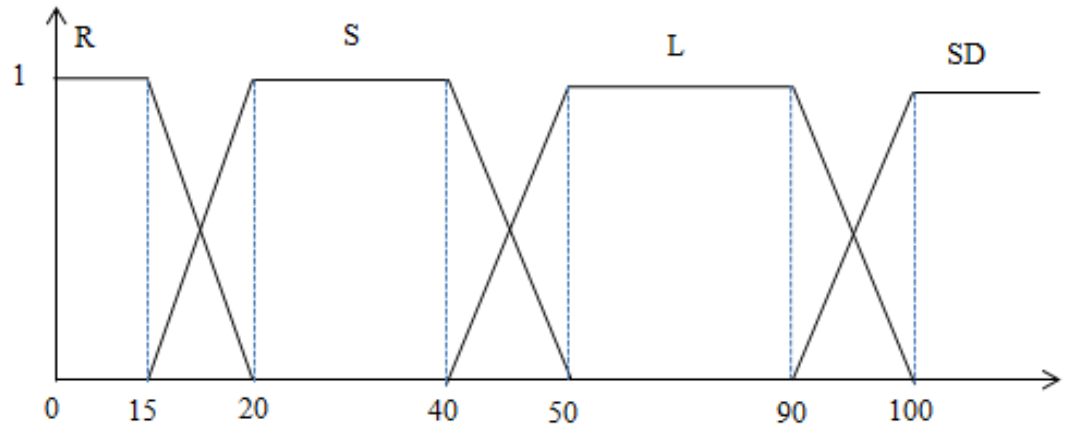

Gambar 7. Kurva Fuzzy pada variabel curah hujan

Persamaan fungsi keanggotaan untuk curah hujan dinyatakan menggunakan persamaan (18), persamaan (19), persamaan (20), dan persamaan (21).

$$
\begin{aligned}
& \mu_{C H R}[x]=\left\{\begin{array}{c}
1, x \leq 15 \\
\frac{20-x}{5}, 15 \leq x \leq 20 \\
0, x \geq 20
\end{array}\right. \\
& \mu_{C H S}[x]=\left\{\begin{array}{c}
0, x \leq 15 \text { atau } x \geq 50 \\
\frac{x-15}{5}, 15 \leq x \leq 20 \\
\frac{50-x}{10}, 40 \leq x \leq 50 \\
1,20 \leq x \leq 40
\end{array}\right. \\
& \mu_{C H L}[x]=\left\{\begin{array}{c}
0, x \leq 40 \text { atau } x \geq 100 \\
\frac{x-40}{5}, 40 \leq x \leq 50 \\
\frac{100-x}{10}, 90 \leq x \leq 100 \\
\frac{50-x}{5}, 50 \leq x \leq 90
\end{array}\right. \\
& \mu_{C H S D}[x]=\left\{\begin{array}{c}
0, x \leq 90 \\
\frac{x-90}{10}, 15 \leq x \leq 20 \\
1, x \geq 100
\end{array}\right.
\end{aligned}
$$


6) Variabel Kerentanan Banjir

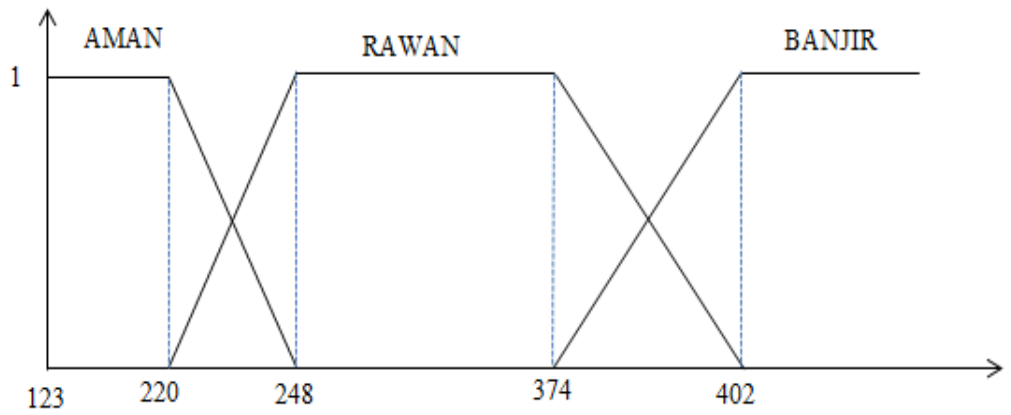

Gambar 8. Kurva himpunan fuzzy pada variabel kerentanan

Persamaan fungsi keanggotaan untuk variabel Kerentanan lahan dinyatakan menggunakan persamaan (22), persamaan (23), dan persamaan (24).

$$
\begin{aligned}
& \mu_{\text {KRAman }}[x]=\left\{\begin{array}{c}
\frac{248-x}{28}, 220 \leq x \leq 248 \\
0, x \geq 248
\end{array}\right. \\
& \mu_{\text {KRRawan }}[x]=\left\{\begin{array}{c}
0, x \leq 220 \text { atau } x \geq 402 \\
\frac{x-220}{28}, 220 \leq x \leq 248 \\
\frac{402-x}{28}, 374 \leq x \leq 402
\end{array}\right. \\
& 1,248 \leq x \leq 374 \\
& \mu_{\text {KRAman }}[x]=\left\{\begin{array}{c}
\frac{x-374}{28}, 374 \leq x \leq 402 \\
1, x \geq 402
\end{array}\right.
\end{aligned}
$$

Selanjutnya dilakukan pengujian dengan menggunakan contoh kasus di Kelurahan Bulu Lor yang mempunyai kepadatan penduduk $25283 \mathrm{jiwa} / \mathrm{km}^{2}$, memiliki das dengan luas 20004,5 ha kemiringan lahanya $2 \%$ dengan ketinggian wilayah hanya 1 mdpl. Terjadi hujan dengan dengan intensitas $17 \mathrm{~mm} / \mathrm{hari}$. Bagaimana tingkat kerentanan banjir di Kelurahan Bulu Lor.

\section{1) Langkah 1. Menentukan Himpunan Fuzzy}

Variabel kepadatan penduduk telah didefinisikan pada empat himpunan Fuzzy yaitu tidak padat, kurang padat, cukup padat, sangat padat. Sehingga diperoleh tingkat keanggotaan variabel kepadatan penduduk $25283 \mathrm{jiwa} / \mathrm{km}^{2}$ yaitu $\mu_{T P}(25283)=0$, $\mu_{K P}(25283)=0, \quad \mu_{C P}(25283)=0, \quad \mu_{S P}(25283)=1$. Yang artinya, kepadatan penduduk tersebut sangat padat dengan tingkat keanggotaan $100 \%$.

Variabel drainase telah didefinisikan pada 5 himpunan Fuzzy yaitu sangat kecil, kecil, sedang, besar dan sangat besar. Sehingga diperoleh tingkat keanggotaan variabel drainase 20004,5 ha yaitu $\mu_{S K}(20.004,5)=0, \mu_{K}(20.004,5)=1, \mu_{S}(20.004,5)=$ $0, \mu_{B}(20.004,5)=0, \mu_{S B}(20.004,5)=0$. Yang berarti drainase kecil dengan tingkat keanggotaan $100 \%$. 
Variabel kelerengan telah didefinisikan pada 5 himpunan Fuzzy yaitu datar, landai, agak curam, curam, dan sangat curam. Sehingga diperoleh tingkat keanggotaan variabel kelerengan $2 \%$ yaitu $\mu_{D}(2)=1, \mu_{L}(2)=0, \mu_{A C}(2)=0, \mu_{C}(2)=0$, $\mu_{S C}(2)=0$. Yang artinya kelerengan datar dengan tingkat keanggotaan $100 \%$.

Variabel ketinggian wilayah telah didefinisikan pada 3 himpunan Fuzzy yaitu rendah, sedang, dan tinggi. Sehingga diperoleh tingkat keanggotaan variabel ketinggian wilayah $1 \mathrm{mdpl}$ yaitu $\mu_{R}(1)=1, \mu_{S}(1)=0, \mu_{T}(1)=0$. Yang berarti ketinggian wilayah rendah dengan tingkat keanggotaan $100 \%$.

Variabel curah hujan telah didefinisikan pada 4 himpunan Fuzzy yaitu ringan, sedang, lebat, dan sangat deras. Sehingga diperoleh tingkat keanggotaan variabel curah hujan $17 \mathrm{~mm} /$ hari yaitu $\mu_{R}(17)=0,6, \mu_{S}(17)=0,4, \mu_{L}(17)=0, \mu_{L}(17)=0, \mu_{S D}(17)=$ 0 . Yang berarti curah hujan ringan dengan tingkat keanggotaan $60 \%$ dan sedang dengan tingkat keanggotaan $40 \%$.

2) Langkah 2. Aplikasi fungsi implikasi

Fungsi implikasi yang digunakan adalah adalah fungsi $M I N$, yaitu dengan mengambil tingkat keanggotaan yang minimum dari variabel input sebagi output. Maka diperoleh aturan :

[R1] Jika KP adalah TP dan D adalah SK dan L adalah D dan KW adalah R dan CH adalah $\mathrm{S}$ maka kerentanan adalah BANJIR

$$
\begin{aligned}
\text { a-predikat }_{1} & =\mu_{K P T P} \cap \mu_{D S K} \cap \mu_{L D} \cap \mu_{K W R} \cap \mu_{C H S} \\
& =\min \left(\mu_{K P T P}(25283), \mu_{D S K}(20004,5), \mu_{L D}(2) \mu_{K W R}(1), \mu_{C H S}(17)\right) \\
& =\min (1 ; 1 ; 1 ; 1 ; 0,4) \\
& =0,4
\end{aligned}
$$

[R2] Jika KP adalah TP dan D adalah SK dan L adalah D dan KW adalah R dan CH adalah $\mathrm{R}$ maka kerentanan adalah BANJIR

$$
\begin{aligned}
\text { a-predikat }_{1} & =\mu_{K P T P} \cap \mu_{D S K} \cap \mu_{L D} \cap \mu_{K W R} \cap \mu_{C H R} \\
& =\min \left(\mu_{K P T P}(25283), \mu_{D S K}(20004,5), \mu_{L D}(2) \mu_{K W R}(1), \mu_{C H R}(17)\right) \\
& =\min (1 ; 1 ; 1 ; 1 ; 0,6) \\
& =0,6
\end{aligned}
$$

3) Langkah 3. Komposisi Aturan

Komposisi aturan merupakan kesimpulan secara keseluruhan dengan mengambil tingkat keanggotaan maksimum dari tiap konsekuen aplikasi fungsi implikasi dan menggabungkan dari semua kesimpulan masing-masing aturan, sehingga didapat daerah solusi Fuzzy sebagai berikut:

$$
\begin{aligned}
\mu_{s f}(x) & =\operatorname{maks}\left\{\mu_{K B}(x)\right\} \\
= & \operatorname{maks}\{0,6\}
\end{aligned}
$$

Titik potong aturan adalah ketika $\mu_{\text {Kerentanan BANJIR }}=0.6$, maka dapat ditentukan nilai $x$ sebagai berikut:

$$
\begin{gathered}
x=374+28 .(0,6) \\
\Leftrightarrow x=374+16,8 \\
\Leftrightarrow x=390,8
\end{gathered}
$$

Sehingga didapat fungsi keanggotaan daerah solusi sebagai berikut:

$$
\mu_{\text {Kerentanan }}=\{0,6 ; 390,8 \leq x \leq 499
$$




\section{4) Langkah 4. Defuzzifikasi}

Defuzzifikasi atau penegasan yaitu untuk mengubah himpunan Fuzzy menjadi bilangan real. Input proses penegasan adalah suatu himpunan Fuzzy, sedagkan output yang dihasilkan merupakan bilangan pada domain himpunan Fuzzy tersebut. Defuzzifikasi yang digunakan dalam menentukan kerentanan banjir adalah Centroid, MOM, LOM, SOM, dan Bisector.

a. Centroid

$$
\begin{aligned}
X= & \frac{\int_{390.8}^{499}(0,6) x d x}{\int_{390,8}^{499} 0,6 d x} \\
= & \frac{\left.0,3 x^{2}\right]_{390,8}^{499}}{0,6 x]_{390,8}^{499}} \\
= & \frac{28882,908}{64,92} \\
& =444,9
\end{aligned}
$$

Nilai kerentanan 444,9 termasuk ke dalam kategori banjir.

b. LOM (Large Of Maximum Method)

Mengambil nilai $\mathrm{z}$ terbesar dari nilai derajat keanggotaan $(\mu(\mathrm{z}))$ yang maksimal. Adapun untuk derajat keanggotaan dapat dilihat pada Tabel 1.

Tabel 1. derajat keanggotaaan $\mu(\mathrm{z})$

\begin{tabular}{ccc}
\hline Rule & $\mu(\mathrm{z})$ & $\mathrm{Z}$ \\
\hline 1 & 0,6 & 390,8 \\
2 & 0,6 & 499 \\
\hline
\end{tabular}

Dari Tabel 1 diperoleh nilai LOM adalah 499. Sehingga berdasarkan perhitungan tersebut kerentanan kelurahan Bulu Lor adalah banjir.

c. SOM (Smallest of Maximum Method)

Mengambil nilai $\mathrm{z}$ terkecil dari nilai derajat keanggotaan $(\mu(\mathrm{z}))$ yang maksimal pada Tabel 1. Dari Tabel 1 diperoleh nilai SOM adalah 390,8. Sehingga berdasarkan perhitungan tersebut kerentanan kelurahan Bulu Lor adalah banjir.

d. MOM (Mean of Maximum Method)

Mengambil nilai $\mathrm{z}$ rata-rata dari nilai derajat keanggotaan $(\mu(\mathrm{z}))$ yang maksimal pada Tabel 1. Dari 1 tersebut diperoleh nilai MOM adalah 444,9. Sehingga berdasarkan perhitungan tersebut kerentanan kelurahan Bulu Lor adalah banjir.

e. Bisector (membagi domain hasil menjadi 2)

Adapun untuk Bisector dengan membagi 2 area derajat keanggotaan yang diperoleh dan megambil nilai z lebih besar dari hasil pembagian derajat keanggotaan pada Tabel 1. Diperoleh nilai Bisector adalah 499. Sehingga berdasarkan perhitungan tersebut kerentanan kelurahan Bulu Lor adalah banjir.

\subsection{Hasil Pengujian}

Setelah dilakukan perhitungan secara manual selanjutnya dilakukan perhitungan menggunakan program kerentanan yang sudah dibuat. 
a) Centroid

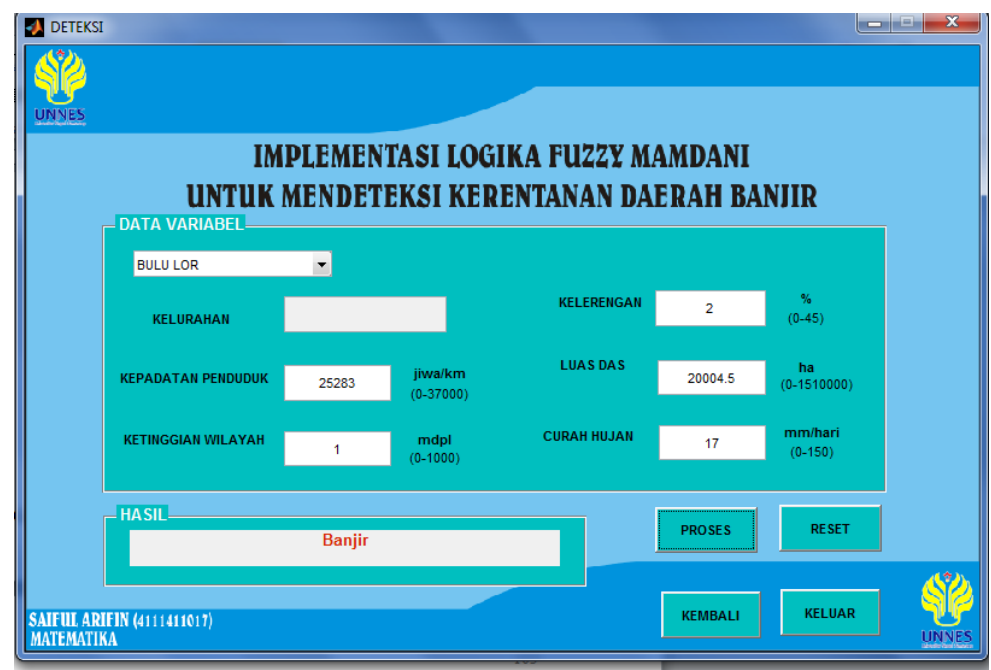

Gambar 9. Hasil deteksi kerentanan daerah banjir kelurahan Bulu Lor

Gambar 9 menunjukkan tingkat kerentananya adalah banjir dengan nilai pada aplikasi menunjukkan 441,5.

b) LOM (Large of Maximum Method)

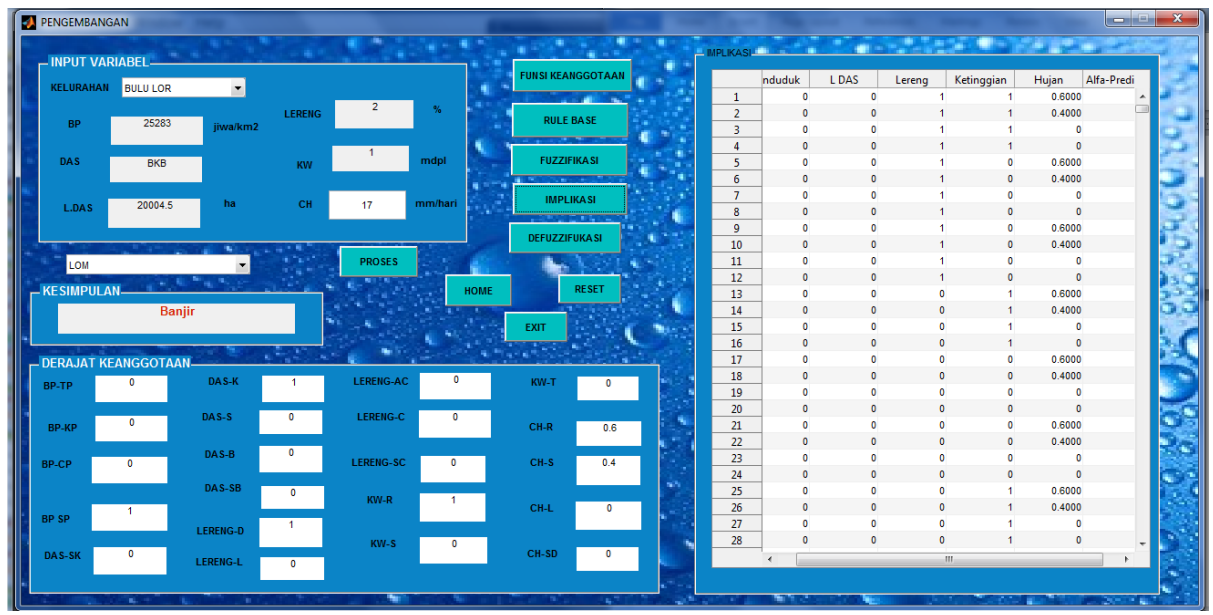

Gambar 10. Program deteksi ketanan

banjir Bulu Lor dengan LOM

Dari Gambar 10 tersebut menunjukkan bahwa Bulu Lor terjadi banjir dengan nilai LOM adalah 499. 
c) SOM (Smallest of Maximum Method)

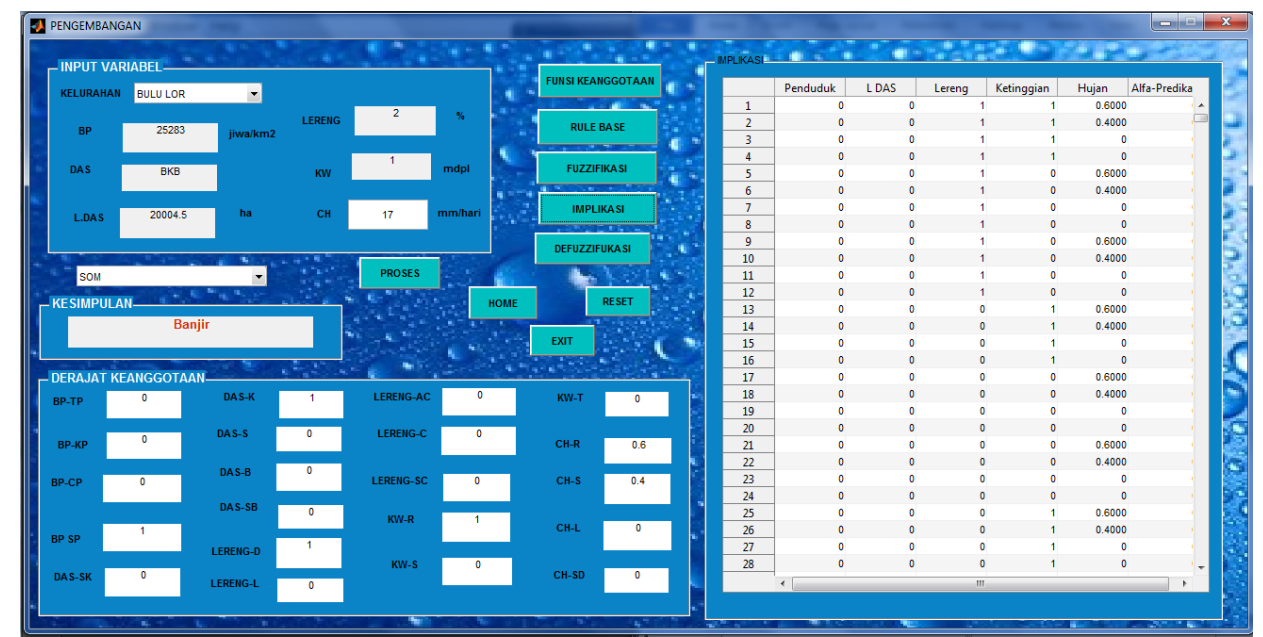

Gambar 11. Program deteksi kerentanan banjir kelurahan Bulu Lor

Dari Gambar 11 menunjukkan bahwa Bulu Lor terjadi banjir dengan nilai SOM adalah 393,72.

d) MOM (Mean of Maximimum Method)

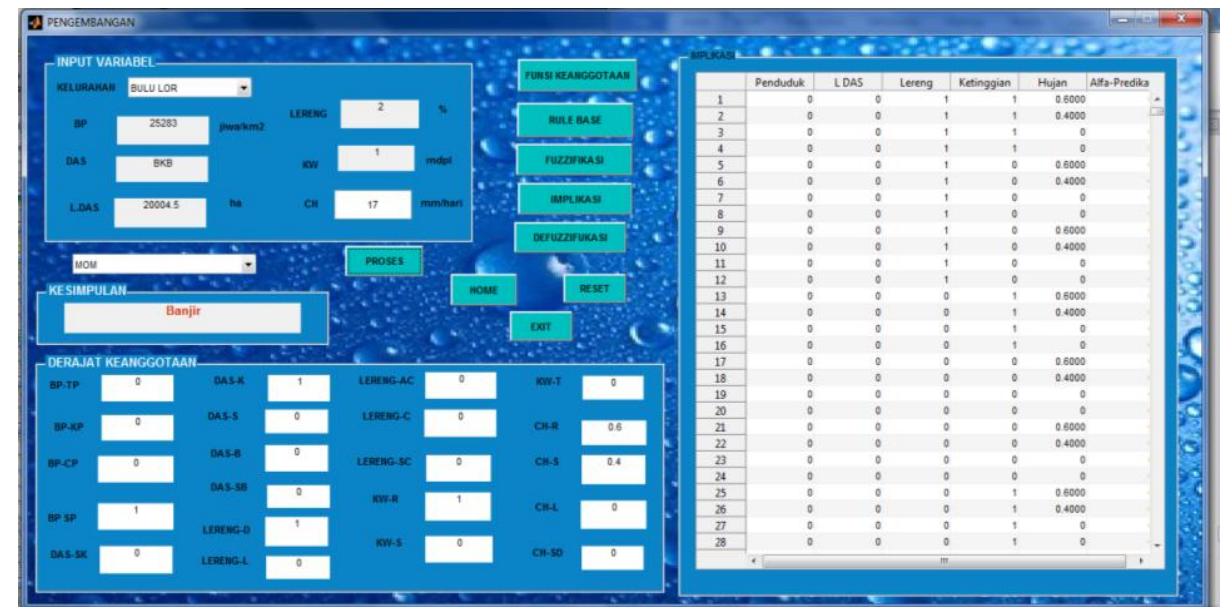

Gambar 12. Program deteksi kerentanan banjir kelurahan Bulu Lor dengan MOM

Dari Gambar 12 menunjukkan bahwa Bulu Lor terjadi banjir dengan nilai SOM adalah 446,36. 


\section{e) Bisector}

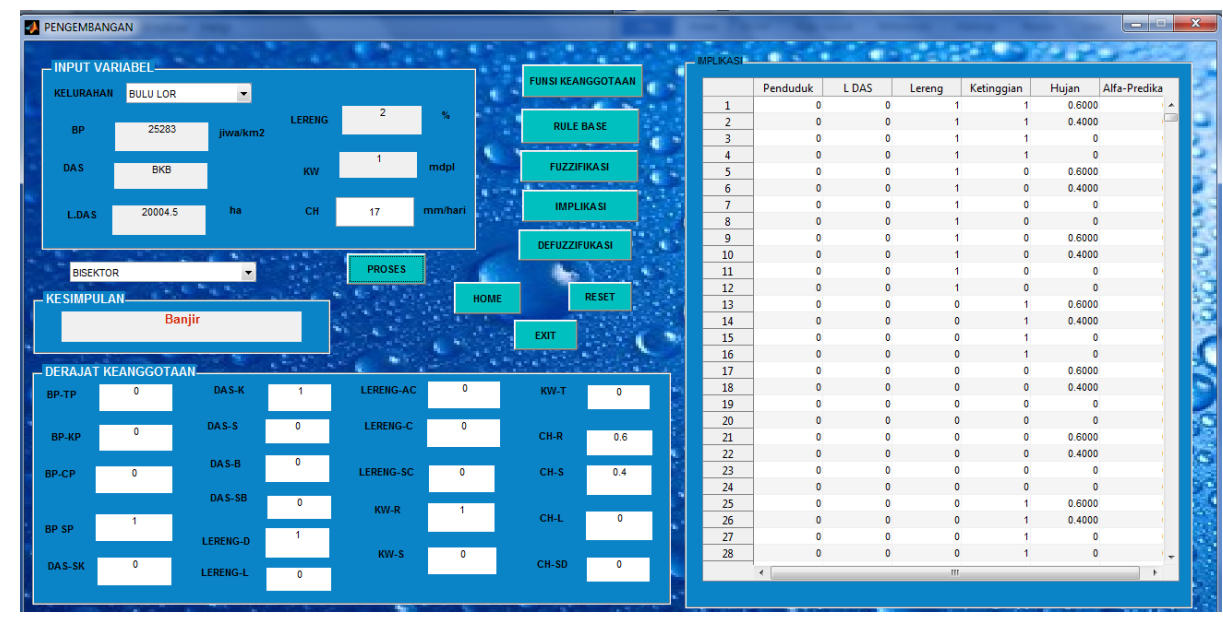

Gambar 13. Program deteksi kerentanan banjir kelurahan Bulu Lor dengan Bisector

Dari Gambar 13 menunjukkan bahwa Bulu Lor terjadi banjir dengan nilai SOM adalah 443,6.

Setelah dilakukan perhitugan secara manual dan program terdapat beberapa kelebihan yang dimiliki aplikasi kerentanan banjir menggunakan Mamdani Fuzzy Inference System antara lain dapat menentukan kerentanan banjir di Semarang Utara lebih mudah, metode yang digunakan dalam aplikasi tidak hanya satu sehingga dapat membandingkan dengan metode lain, efisien karena tidak membutuhkan waktu yang lama.

Sedangkan kekurangan yang dimiliki program kerentaan banjir adalah hasil dari nilai input yang memiliki selisih meskipun kesimpulanya sama. Variabel yang digunakan hanya 5 variabel.

\section{SIMPULAN}

Dari contoh kasus diketahui bagaimana mengimplementasikan logika Fuzzy Mamdani untuk mendeteksi kerentanan daerah banjir di Semarang Utara yaitu dengan melalui 4 langkah yaitu menentukan himpunan Fuzzy, aplikasi fungsi implikasi, komposisi aturan, dan defuzzifikasi. Sehingga diperoleh hasil dari kasus kelurahan Bulu Lor dengan metode Centroid banjir, LOM adalah banjir, SOM adalah banjir, MOM adalah banjir, dan Bisector adalah banjir. Pembangunan program deteksi kerentanan daerah banjir dimulai dengan pembentukan Fuzzy Inference System dengan menggunakan Fuzzy logic toolbox pada software Matlab R2013a. FIS yang dibentuk akan digunakan dalam proses pembentukan sistem adalah pembuatan desain interface menggunakan graphic user interface, kemudian dilanjutkan dengan melengkapi kode pada software Matlab R2013a. setelah program deteksi kerentanan banjir dibuat, data monografi di-input-kan. Selanjutnya dilakukan pengujian sistem dengan melakukan defuzzifikasi sehingga didapatkan hasil deteksi kerentanan daerah banjir di kelurahan Semarang Utara. 


\section{REFERENSI}

[1] Kodoati, R. J, dan Sugiyanto. 2002. Banjir, Beberapa Penyebab dan Metode Indoesia. Badan Koordinasi Penanggulangan Bencana, Jakarta.

[2] Kusumadewi, S. 2008. Sistem Inferensi Fuzzy (Metode TSK) untuk Penentuan Kebutuhan Kalori Harian. Universitas Islam Indonesia, Yogyakarta.

[3] Kusumadewi, S. dan Purnomo. 2010. Aplikasi Logika Fuzzy untuk Pendukung Keputusan. Graha Ilmu, Yogyakarta. 